\title{
Public Accounting Research and Theories: A Literature Review
}

\author{
Faiz Zamzami ${ }^{1 *}$, Mukhlis ${ }^{2}$
}

\section{AFFILIATION:}

${ }^{1}$ Doctorate Student, Faculty of Economic and Business, Universitas Gadjah Mada, Indonesia

1,2Department of Public Sector Accounting, Vocational School, Universitas Gadjah Mada,

Yogyakarta, Indonesia

\section{*CORRESPONDENCE: \\ faiz@ugm.ac.id}

THIS ARTICLE IS AVAILABLE IN:

https://ojs.unud.ac.id/index.php/jiab

\section{DOI:}

10.24843/JIAB.2021.v16.i01.p08

\section{CITATION:}

Zamzami, F. \& Mukhlis. (2021). Public Accounting Research and Theories: A Literature Review. Jurnal Ilmiah Akuntansi dan Bisnis, 16(1), 115-136.

\section{ARTICLE HISTORY}

Received:

13 February 2020

Revised:

06 October 2020

Accepted:

05 January 2021

\begin{abstract}
The purpose of this study is to provide a structured overview of the literature on research on public accounting and the theories used by referring to articles published in four reputable international journals in 2009-2018. A literature review-based approach with two important steps in the analysis of trends in public accounting research was used. First, journals as the source of the data are limited to four reputable international journals that published public sector research. Second, articles are divided into three areas that include financial accounting, management accounting, and auditing. A structured method was then used to analyze the relevant and identified articles. Results show that articles published in four leading international journals do not specifically discuss public accounting. So far, journals publishing public accounting remain rare. Of the four journals, articles in public reports are few. Ten popular theories on how to apply public accounting research were discussed.
\end{abstract}

Keywords: public accounting, literature review, financial accounting, management accounting, auditing

\section{Introduction}

Accounting both for public organizations and business organizations are upstream accounting despite differences. The differences include the motives, backgrounds and objectives of the organization and methods to achieve the goals set. The sources and characteristics of organizational funding are also different (Ritonga, 2020). To ensure an adequate understanding of the research development in public accounting and the theories used, a systematic analysis is required to analyze what has been published in reputable journals to date. This study presents the results of a literature review in a summary of articles published in four reputable international journals and compiles a review of the theories used in the field of public accounting. This study aims to assist students and researchers in the field of public accounting by providing a framework for the trends in public accounting research and theories to be used more precisely and focused given the unique characteristics of public sector organizations. This discussion is carried out by providing an overview of 
Zamzami \& Mukhlis

Public Accounting Research and Theories: A Literature Review

the trends about what has been published in articles in reputable journals this far.

This study focuses on the field of public accounting, which falls into public sector financial accounting, public sector management accounting, and public sector auditing. The three categories assist the readers to review the trends of the article themes over time. Furthermore, this study discusses the most suitable theory for this type of research. Thus, the literature review will be a useful starting point for interested students or researchers.

This study gives three important contributions. First, it develops a comprehensive review of public sector accounting research. Second, it identifies the main themes and insights of research in the last ten years and their different attributes as a specialized area in the literature of public sector accounting. Third, it consolidates the main distinctive themes, and identifies the theory used.

\section{Research Method}

This study uses a literature review of research results published in four reputable journals in 2009 - 2018. Two important steps were therefore used in analyzing trends in public accounting research. First, the journals as the data source are limited to four reputable international journals that have regularly published public sector research. Second, articles are divided into three areas that include financial accounting, management accounting and auditing. Articles relevant to this study were analyzed using a structured method.

Reputable international journals were selected to obtain an overview of international researches in the last ten years that focus on the accounting literature. As a result, most public accounting articles could be identified despite possibility that some articles were overlooked.

Given the numerous potential journals available, the choice for which accounting journals to include was based on the four most influential international journals in the field of public accounting. Lacking specialized journals in the field of public accounting in the international scope public accounting research are mostly in public sector journals that contain general articles with a limited scope to the public sector. The four journals include Journal of Public Budgeting, Accounting \& Financial Management; Accounting, Auditing \& Accountability Journal; International Journal of Public Sector Management; and the American Review of Public Administration.

After identifying the most influential accounting journals which published public sector research, and by referring to several important articles, as suggested by (Neu, 1991a, 1991b, 1991c), (Tomkins, 2001), and (Baldvinsdottir et al., 2011), 2009- 2018 was set as the time period for reviewing articles. The number of articles in the selected journals was grouped on the basis of the publication year as Table 1. presents.

After a number of potential articles in 4 journals were identified, articles specifically related to public accounting were divided into three categories including public sector financial accounting, public sector management accounting, and public sector auditing. Electronic search was conducted to identify all articles that discuss the three fields. The theories in this paper were identified from articles published in reputable international journals by observing how the articles were applied. 


\section{Result and Discussion}

Publications of public accounting research in four reputable international journals show different trends annually. Table 1. reviews the number of public accounting research in the four reputable international journals. The Journal of Public Budgeting, Accounting \& Financial Management and the International Journal of Public Sector Management have consistently presented articles that review public accounting in the last ten years. The American Review of Public Administration presents articles that discuss public accounting despite small proportions. Meanwhile, Accounting, Auditing \& Accountability Journal published public accounting issues in 2015 only.

To present an overview of what types of topics have been summarized into three categories, Table 2. presents classification based on the topic areas and shows that financial accounting is clearly the most common research topic among the articles identified, followed by management accounting and auditing.

Articles in the four journals were identified and classified based on their publication year. Table 2. shows the changing number of articles published in these four categories each year. It is therefore a great opportunity for researchers to submit articles to the journals.

Table 2. shows that each theme can be made detailed to obtain elaborated themes of the articles for the last ten years. This review will be discussed in Table 3-5.

In the field of public sector financial accounting, as referred to Appendix 1. Journal of Public Budgeting, Accounting \& Financial Management shows that research trends in the last two years have consistently discussed the implementation of accounting standards and consolidated financial statements.

In the field of public sector financial accounting, according to Appendix 2., Accounting, Auditing \& Accountability Journal merely discussed public accounting in 2015 only. Despite that only three articles were published, the themes remained relevant for further research.

Focusing on the field of public sector financial accounting, as to refer to Appendix 3., the International Journal of Public Sector Management reveals that this

Table 1. The Number of Trends in Public Accounting Research

\begin{tabular}{|c|c|c|c|c|c|c|c|c|c|c|c|}
\hline \multirow{4}{*}{ Name of Journals } & 2 & 2 & 2 & 2 & 2 & 2 & 2 & 2 & 2 & 2 & \multirow{4}{*}{ Total } \\
\hline & 0 & 0 & 0 & 0 & 0 & 0 & 0 & 0 & 0 & 0 & \\
\hline & 0 & 1 & 1 & 1 & 1 & 1 & 1 & 1 & 1 & 1 & \\
\hline & 9 & 0 & 1 & 2 & 3 & 4 & 5 & 6 & 7 & 8 & \\
\hline $\begin{array}{l}\text { Journal of Public } \\
\text { Budgeting, Accounting \& } \\
\text { Financial Management }\end{array}$ & 5 & 8 & 2 & 5 & 4 & 9 & 3 & 0 & 1 & 5 & 42 \\
\hline $\begin{array}{l}\text { Accounting, Auditing \& } \\
\text { Accountability Journal }\end{array}$ & 0 & 0 & 0 & 0 & 0 & 0 & 3 & 0 & 0 & 0 & 3 \\
\hline $\begin{array}{l}\text { International Journal of } \\
\text { Public Sector } \\
\text { Management }\end{array}$ & 7 & 3 & 5 & 3 & 3 & 0 & 2 & 3 & 1 & 3 & 30 \\
\hline $\begin{array}{l}\text { The American Review of } \\
\text { Public Administration }\end{array}$ & 2 & 0 & 0 & 1 & 0 & 1 & 0 & 1 & 3 & 10 & 18 \\
\hline
\end{tabular}

Source: Processed Data, 2020 
Zamzami \& Mukhlis

Public Accounting Research and Theories: A Literature Review

Table 2. Public Accounting Research Themes

\begin{tabular}{lrrrrrrrrrrr}
\hline \multirow{4}{*}{ Theme } & 2 & 2 & 2 & 2 & 2 & 2 & 2 & 2 & 2 & 2 & \\
& 0 & 0 & 0 & 0 & 0 & 0 & 0 & 0 & 0 & 0 & Total \\
& 0 & 1 & 1 & 1 & 1 & 1 & 1 & 1 & 1 & 1 & \\
\hline $\begin{array}{l}\text { Financial Accounting } \\
\text { Management }\end{array}$ & 9 & 0 & 1 & 2 & 3 & 4 & 5 & 6 & 7 & 8 & 42 \\
$\begin{array}{l}\text { Accounting } \\
\text { Audit }\end{array}$ & 8 & 2 & 6 & 4 & 3 & 2 & 1 & 2 & 2 & 4 & 34 \\
Total & 2 & 3 & 1 & 3 & 2 & 1 & 1 & 1 & 0 & 3 & 17 \\
\hline
\end{tabular}

Source: Processed Data, 2020

journal does not publish articles that discuss public accounting in a certain period of time. This journal consistently discusses the accrual basis, sustainability and disclosure. These research themes are subject to development to date.

In the journal The American Review of Public Administration, referring to Appendix 4., the theme of public sector financial accounting has been few in number from year to year but more financial accounting themes have been published recently. This journal discusses more issues of disclosure, accrual basis, and sustainability.

The following will discuss articles in the four international journals that specifically review management accounting. Journal of Public Budgeting, Accounting \& Financial Management discusses more about budget issues and performance appraisal of public sector organizations as the themes presented in Appendix 5.

The International Journal of Public Sector Management presents the discussion of public sector management accounting more on the issues of performance appraisal of public sector organizations, new public management, financial management as the theme presented in Appendix 6.

In the last journal, the discussion of public sector management accounting in the American Review of Public Administration focuses more about issues of budgeting systems, new public management, and performance measurement as presented in Appendix 7.

The third field, public sector auditing, presents a detailed discussion of the three journals that specifically review public sector audits comprising the Journal of Public Budgeting, Accounting \& Financial Management as showed in Appendix 8. The journal reviews issues on auditor behavior, audit fees, and audit finding reports. However, no articles discussed public sector auditing in the period of 2016 and February 2019.

Table 3. Research Themes in Financial Accounting

\begin{tabular}{|c|c|c|c|c|}
\hline \multirow[b]{2}{*}{$\begin{array}{l}\text { Research } \\
\text { Theme }\end{array}$} & \multicolumn{4}{|c|}{ Name of Journals } \\
\hline & $\begin{array}{l}\text { Journal of } \\
\text { Public } \\
\text { Budgeting, } \\
\text { Accounting \& } \\
\text { Financial } \\
\text { Management }\end{array}$ & $\begin{array}{l}\text { Accounting, } \\
\text { Auditing \& } \\
\text { Accountabilit } \\
\text { y Journal }\end{array}$ & $\begin{array}{l}\text { International } \\
\text { Journal of } \\
\text { Public Sector } \\
\text { Management }\end{array}$ & $\begin{array}{c}\text { The } \\
\text { American } \\
\text { Review of } \\
\text { Public } \\
\text { Administrati } \\
\text { on }\end{array}$ \\
\hline $\begin{array}{l}\text { Financial } \\
\text { Management }\end{array}$ & $\mathrm{V}$ & & $\sqrt{ }$ & $\mathrm{V}$ \\
\hline
\end{tabular}

Source: Processed Data, 2020 
Zamzami \& Mukhlis

Public Accounting Research and Theories: A Literature Review

Table 4. Research Themes in Management Accounting

\begin{tabular}{|c|c|c|c|c|}
\hline \multirow[b]{2}{*}{ Research Theme } & \multicolumn{4}{|c|}{ Name of Journals } \\
\hline & $\begin{array}{l}\text { Journal of } \\
\text { Public } \\
\text { Budgeting, } \\
\text { Accounting \& } \\
\text { Financial } \\
\text { Management }\end{array}$ & $\begin{array}{c}\text { Accounting, } \\
\text { Auditing \& } \\
\text { Accountability } \\
\text { Journal }\end{array}$ & $\begin{array}{c}\text { International } \\
\text { Journal of Public } \\
\text { Sector } \\
\text { Management }\end{array}$ & $\begin{array}{l}\text { The American } \\
\text { Review of } \\
\text { Public } \\
\text { Administration }\end{array}$ \\
\hline Budgeting & $\mathrm{V}$ & & & $\mathrm{V}$ \\
\hline $\begin{array}{l}\text { Performance } \\
\text { Appraisal }\end{array}$ & v & & v & v \\
\hline $\begin{array}{l}\text { New public } \\
\text { management }\end{array}$ & & & v & v \\
\hline $\begin{array}{l}\text { Financial } \\
\text { Management }\end{array}$ & & & v & \\
\hline
\end{tabular}

Source: Processed Data, 2020

The International Journal of Public Sector Management, as per Appendix 9., does not regularly publish articles on public sector auditing. The issues discussed in this journal include audit performance and internal audit contributions.

At last, referring to Appendix 10., the discussion of public sector auditing in the American Review of Public Administration was fewer compared to previous journals. The hot issues to be discussed in this journal comprise the independence of internal audit in government. The small number of public sector auditing articles in this journal opens a new opportunity for new researches.

Accounting theories are developed and rediscovered from the results of studies using both simultaneous qualitative and quantitative approaches. The developing

Table 5. Research Themes in Auditing

\begin{tabular}{|c|c|c|c|c|}
\hline \multirow[b]{2}{*}{$\begin{array}{l}\text { Research } \\
\text { Theme }\end{array}$} & \multicolumn{4}{|c|}{ Name of Journals } \\
\hline & $\begin{array}{l}\text { Journal of } \\
\text { Public } \\
\text { Budgeting, } \\
\text { Accounting \& } \\
\text { Financial } \\
\text { Management }\end{array}$ & $\begin{array}{c}\text { Accounting, } \\
\text { Auditing \& } \\
\text { Accountabilit } \\
\text { y Journal }\end{array}$ & $\begin{array}{l}\text { International } \\
\text { Journal of } \\
\text { Public Sector } \\
\text { Management }\end{array}$ & $\begin{array}{c}\text { The } \\
\text { American } \\
\text { Review of } \\
\text { Public } \\
\text { Administrati } \\
\text { on }\end{array}$ \\
\hline $\begin{array}{l}\text { Auditor } \\
\text { Behavior }\end{array}$ & $\mathrm{V}$ & & & \\
\hline $\begin{array}{l}\text { Audit Fee } \\
\text { Investigation }\end{array}$ & $\mathrm{v}$ & & & \\
\hline $\begin{array}{l}\text { Audit Finding } \\
\text { Report }\end{array}$ & v & & & \\
\hline $\begin{array}{l}\text { Audit } \\
\text { Performance }\end{array}$ & & & $v$ & \\
\hline $\begin{array}{l}\text { Internal Audit } \\
\text { Contribution }\end{array}$ & & & $\sqrt{ }$ & \\
\hline Independency & & & & $v$ \\
\hline
\end{tabular}

Source: Processed Data 
researches are not only related to accounting processes and technology, but also the behavior of the people using the theories. Some of the theories used in public accounting research are relevant with the studies conducted in four reputable journals are as follows.

First, entity theory. This theory argues that an organization is an independent entity separated from the groups or individuals associated with the organization. Entity theory is based on the equation: $\Sigma A=\Sigma K+S E$, or Asset = Equity (Liabilities plus Shareholder's Equity). It implies that the organization's business activity become an independent unit beyond the owner's identity, suggesting a division between personal interests and organizational interests.

An example of research using entity theory in building hypotheses was found in the article written by Gardini (2014) titled "Voluntary Adoption of the Consolidated Financial Statement and Fair Value Accounting by Italian Local Governments". The article reviews the potential benefits of fair value accounting in the public sector and discusses the shift towards a consolidated entity theory supported by international accounting standards. The research results indicate that the results of the analysis of cases observed in Italy do not show the adjustment of assets to their fair value, or the recognition of intangible assets other than goodwill in the consolidated financial statements, retaining the group configuration based on historical cost. The results demonstrate less focus on the application of fair value by local governments, which is different from international accounting standards. This researcher develops entity theory by applying to the accounting process of preparing consolidated financial statements based on a map of potential stakeholders such as minority interests, regulatory bodies, short and long term creditors, management and dominant shareholders.

Another article that applies entity theory was written by Prabowo et al., (2017). It discusses the use of entity theory and argues that the rule base system requires that entities must follow numerous detailed accounting rules to comply with the Generally Accepted Accounting Principles (GAAP). Designers of Accounting standards set specific accounting rules for each specific entity and therefore the entity must understand and follow all detailed accounting rules.

Second, agency theory. Agency theory was introduced by Berle \& Means (1932). The theory states that an organization or party is the principal who assigns agents to work on behalf of the organization. The relationship between the principal and the agent is based on a contract made by the principal either implicitly or explicitly, with the agent. The contract ensures that the agent will carry out the work and authority as expected by the principal.

Jensen \& Meckling, (1976) integrate elements from the agency theory, property theory and financial theory to develop a theory of company ownership structure. This agency relationship results in two problems including Information Asymmetry and Conflict of Interest. Agency costs resulting from the problems consist monitoring costs, bonding costs and residual loss. Fama \& Jensen (1983) suggest that agency costs may arise when the principal delegates decision-making authority to the agent.

This theory was widely used in the reviewed articles. First, research conducted by Stalebrink (2014) in an article entitled "Public Pension Funds and Assumed Rates of Return: An Empirical Examination of Public Sector Defined Benefit Pension Plans". This article adopts assumptions on the return on investment associated with public sector defined benefit pension plans. This study uses the Principal - Agent theory, the common 


\section{Zamzami \& Mukhlis}

Public Accounting Research and Theories: A Literature Review

theory in the accounting system. Accounting discloses information that reduces the information asymmetry emerging when decisions are delegated from the principal to the agent. In the context of the given research, the principals are the heads and the general public, while the agents are the investment boards.

Second, research conducted by Gordon \& Fischer (2014) in an article entitled "Public University Presidential Compensation: Performance, Cost Efficiency and Spending Choices". Gordon \& Fischer (2014) are interested in cost containment in public higher education, and believe that performance should be measured based on cost efficiency and expenditure choices. The study uses agency theory which predicts that changes in reporting models allowing stakeholders to evaluate expenditure options are likely to result in mission objectives-focused spending choices.

Third, research conducted by Waluyo (2018) with an article entitled "Balancing Financial Autonomy and Control in Agencification: Issues Emerging from the Indonesian Higher Education". In this article, Waluyo examines the autonomy of higher education management in the agent's perspective. As the principal, the Indonesian government gives an autonomy and semi-autonomy to universities as agents in which the delegation of authority includes policy and management of finance, human resources and asset resources.

Fourth, research conducted by Ríos et al. (2016) with an article entitled "Budget Transparency and Legislative Budgetary Oversight". This research put citizens as the principal represented by the legislative body, while government officials serve as agents. Agency theory claims that citizens and politicians / government officials may not pursue the same goals, because politicians have their own interests, which do not necessarily maximize citizen welfare. Citizens therefore need to pressure politicians / officials to disclose information for minimized information asymmetry and to enable citizens to monitor their activities (Zimmerman, 1977). Budget supervision by a critical legislature, and external audits by a credible accounting firm become the main mechanisms of financial accountability.

Fifth, research conducted by Aikins (2012) with an article entitled "Determinants of Auditee Adoption of Audit Recommendations: Local Government Auditors' Perspectives". This study describes the relationship between agency theory and the importance of auditing for government executives. As an agent, the government has more information than the principal (citizens). As a result, it creates information asymmetry that triggers moral hazard and the effectiveness of whether or not the interests of citizens are served well by the government. Therefore, citizens demand greater accountability for the management out by the government and call for the role of auditors to examine operational efficiency, compliance with regulations and procedures reliability of financial records, safeguarding assets and achieving the objectives of governance.

Third, legitimacy theory. As proposed by Lindblom (1994) and Guthrie \& Parker (1989), the legitimacy theory is based on a premise that organizations will continue to exist if the society realizes that the organization operates for a value system which suits the society's own value system.

Marcuccio \& Steccolini (2009) in an article entitled "Patterns of Voluntary Extended Performance Reporting in Italian Local Authorities", this research uses legitimacy theory, which argues that the higher the visibility of an organization, the greater attention is given to the quality and quantity of information disclosed. To 
develop the formulated hypothesis, the researcher hypothesizes that local authorities in Italy can be expected to make stronger efforts to disclose information about performance aspects. The results of the research show that no significant relationship was identified between visibility pressure and the level of disclosure. In addition, there is a negative relationship between external pressure on environmental problems and the quantity of environmental disclosure on social reports.

Fourth, institutional theory. Scott (2004) argues that institutional theory pays deep and serious attention to social structures. The theory views how structures such as schemes, rules, norms and routines become authoritative forms for social behavior to occur. Institutional theory is used in several studies related to measuring the performance of the public sector. This study aims to determine the extent to which the development of performance measurement systems is affected by the phenomenon of coercive, mimetic, and normative isomorphism.

This theory was used in several articles. The first, an article entitled A twocountry comparison of public sector accounting reforms: Same ideas, different paths?" written by Timoshenko \& Adhikari (2010). The research aims to make a comparison between two countries that seem unique from the public sector accounting reforms in developing countries and countries in transition such as Nepal and Russia. The institutional theory was applied as a suitable theoretical tool in research conducted by Timoshenko \& Adhikari (2010) as it relates to the question of how organizations adapt to the rules in the environment in which they are embedded Bergevärn et al. (1995). This study attempts to collect data through an archive of official documents, accounting policies, regulations, and other types of accounting guidelines related to each country. In addition, the data collected are the results of studies and recommendations gathered in each country as issued by international organizations such as the World Bank, International Monetary Fund, Transparency International, and the Asian Development Bank (ADB).

Secondly, Greiling et al. (2015) in an article entitled "Sustainability Reporting in the Austrian, German and Swiss Public Sector". Using institutional theory, the study discusses sustainable reporting. In the public sector, stakeholders can consist of parliamentary bodies, supervisory boards, public supervisory committees, consumer councils, audit offices, public sector supervisors, and others as relevant users, for which the use of institutional theory is used because people would expect isomorphism related to reporting sustainability of public sector organizations. It is expected to generate more comprehensive effects on sustainability reports in response to public pressure.

Third, Gigli \& Mariani (2018) in an article entitled "Lost in the Transition From Cash to Accrual Accounting: Assessing the Knowledge Gaps in Italian Public Universities" also uses new institutional theory. This research examines changes in the use of basic accounting. cash to accrual basis by identifying and assessing institutional and organizational obstacles that can affect this process. The results of this study conclude that the low level of compliance with the accrual accounting system and the budgeting system was due to the lack of accrual accounting culture in the Italian public sector.

Fourth, this theory was also used by Verbeeten (2011) in an article entitled "Public Sector Cost Management Practices in The Netherlands" to analyze the increasing need for and use of cost management information in the public sector in the Netherlands. Cost management information provides a variety of information that can 


\section{Zamzami \& Mukhlis}

Public Accounting Research and Theories: A Literature Review

be used for several purposes, to formulate strategies, transform strategies into plans and budgets, coordinate and communicate activities within the organization, set prices, and to provide benchmarks for evaluating performance (Kaplan \& Johnson, 1987). Besides, cost management information may also be required due to legal terms such as financial reporting and maximum pricing regulations.

A number of studies reviewed the purpose of using cost management information in public sector organizations. Paulsson (2006) study found that the Swedish central government uses cost management information for planning, budgeting and performance evaluation.

Fifth, economic theory. Economic theory explains economic phenomena to answer the question about why and how economy behaves and what is the best solution for solving the economic phenomena. This theory develops from classical, neoclassical, keynesia, neo-keynesian, and post-keynesian economics.

Several articles using the first economic theory. Copley \& Douthett (2014) in an article entitled "Are Governmental Accounting Measures Value Relevant to the Citizenry" tries to implement the economic theory put forward by Yinger (1982) in examining the role of government accounting information in Yinger (1982) economic theory on factors determining housing value. Yinger (1982) predicts that house prices are determined by the expectations of household movers regarding the level of service and future government taxes in a particular jurisdiction. Accounting information plays a role in Yinger's model if government disclosures about current performance are useful for home buyers in shaping expectations about future taxes and services. The study found that changes in housing prices are inversely related to changes in tax and debt rates, and are directly related to reported general fund surplus or deficit reported by the government.

Secondly, Kidwell \& Lowensohn (2018) in an article entitled "Stakeholder Participation in the Governmental Accounting Standard-Setting Process" also uses economic theory. It refers to Roberts \& Kurtenbach (1992) who argue that under regulatory economic theory compilers and assessors (auditors) can negotiate for the activities of the Governmental Accounting Standards Board (GASB) for their own best interest. The results of research by Kidwell \& Lowensohn (2018) support the regulatory economic theory as applied to the GASB negotiation (Roberts \& Kurtenbach, 1992).

Sixth, conventional financial theory. Conventional financial theory was developed in the 1960's. Conventional financial concepts assume that financial markets are perfect and that their participants are rational wealth maximizers. In such an arrangement, any deviation from the equilibrium value of the security due to irrational traders, is quickly identified and eliminated by rational wealth maximization by establishing riskless arbitrage as suggested by Friedman (1953). The influential argument by Friedman (1966) suggests that theories should not be judged from their realism. The assumptions should be deeply evaluated based on the validity of their predictions.

Plummer and Patton (2015) in an article entitled "Using Financial Statements to Provide Evidence on the Fiscal Sustainability of the States" implemented conventional financial theory in their research. The study applies conventional financial theory in analyzing pension obligation as reflected in the finding that 40 states have postponed payments for past expenses into future periods, with the median deferred cost of $\$ 6.7$ billion per state or $\$ 5,230$ per household. The deficit values are also significant when compared to the country's current annual tax revenue. 


\section{Zamzami \& Mukhlis}

Public Accounting Research and Theories: A Literature Review

Seventh, the debt overhang theory. This theory was formally put forward by Myers (1977). The Debt Overhang Theory argues that increased debt in an organization can encourage shareholders to invest less in profitable projects given that the higher the level of debt the organization is, the future positive Net Present Value (NPV) is overlooked due to difficulties in financing. This theory is applied to research in the public sector as conducted by Magnus et al. (2003), Bowman (2002), Yetman (2007).

One of the reviewed article was written by Charles (2017) entitled "Nonprofit Arts Organizations: Debt Ratio Does Not Influence Donations - Interest Expense Ratio Does". The study investigates whether capital structure decisions made by nonprofit managers affect the future contributions of individual donors. In particular, the researcher asks whether or not debt is associated with a lower financial support in the future. Referring to previous research which also used the debt overhang theory. the results of the study showed that donors can annul support to nonprofit organizations that use debt to finance capital acquisitions and those who use donations to pay off their debts instead of funding programs.

Eighth, resource dependence theory. Resource dependence theory was introduced in the 1970s by Jeffrey Pfeffer and Gerald R. Salancik who argue that as an open system, organizations need to transact with other organizations in their environment to obtain the necessary resources for surviving. The resources consist of financing including debt and equity, social legitimacy, receiving funds from the provision of the organization's results to other parties and the inputs needed to produce the products and services offered. This theory explains how organizations can adapt to and adjust with the environment, so that organizations take the environment as a strong constraint for operation.

One of the articles that reviews Resource dependence theory is Cohen \& Karatzimas (2018) was entitled "The Role Of The Troika On The Greek Central Government Accounting Reforms: The Reprioritization Riddle". The study aims to explore Troika's role in budgeting progress and reforms in the financial reporting system at the Greek central government. The application of this theory offers valuable insight in analyzing public financial management reforms in countries that experience financial crises. This study observes and monitors activities during the financial crisis. Organizations must be able to get adapted and adjust with the environment. The finding suggests that Greece must comply with the requirements of resource providers and fulfill obligations for an access to appropriate resources.

Ninth, the balanced scorecard (BSC) theory. Initially used in the private sector, $\mathrm{BSC}$, the performance management tool has also been used in the public sector. BSC provides performance management information in four balanced perspectives comprising innovation and learning, internal business processes, customers, and finance. Not only ensures balance, BSC also provides a comprehensive framework, in which each perspective has a causal relationship with other perspectives (Kaplan \& Norton, 1992). The achievement or improvement in innovation and learning will promote internal business processes, while the achievement in internal business processes will boost customer satisfaction. In the end, customer satisfaction will improve opinions. In addition, better innovation and internal business processes also increases operating effectiveness and also encourages cost efficiency, which encourages increased profits or benefits for the organization. 


\section{Zamzami \& Mukhlis}

Public Accounting Research and Theories: A Literature Review

This theory was applied in Northcott \& Taulapapa (2012) research entitled "Using the Balanced Scorecard to Manage Performance in Public Sector Organizations". Northcott \& Taulapapa (2012) used this theory to examine the use of BSC as a performance management tool in the public sector particularly in New Zealand, and to identify problems and challenges in its application.

\section{Conclusion}

The articles published in 4 leading international journals do not specifically discuss public accounting. Journals that specifically present public accounting have not been widely available. Of the four journals, articles that contain and discuss topics regarding public accounting are few in each category. The category comprises public sector financial accounting, public sector management accounting, and public sector auditing. Public sector auditing has a bigger opportunity to be published more in reputable international journals. For the future research, the field of the public sector can still be well developed, especially in studies related to the behavior and implementation of good government governance by public sector organizations given numerous obstacles. The theories identified and discussed above consist of 9 popular theories. The theories are interesting to be applied in the public accounting research.

This paper was made limited to 4 reputable international journals. The future research is expected to identify more than 20 accredited international and national journals in a particular country given that the topics of public accounting in each country are unique by nature. 9 theories were selected among the theories discussed in the articles in the four reputable international journals. They represent the most popularly used theories by international researchers. The future research can identify the overall theories used and applied to the public sector research to make sure that readers can easily apply theories to the undertaken research.

\section{References}

Aikins, S. K. (2012). Determinants of Auditee Adoption of Audit Recommendations: Local Government Auditors' Perspectives. Journal of Public Budgeting, Accounting \& Financial Managemen, 24(2), 195-220. https://doi.org/10.1108/JPBAFM-24-022012-B002

Baldvinsdottir, G., Hagberg, A., Johansson, I. L., Jonäll, K., \& Marton, J. (2011). Accounting research and trust: A literature review. Qualitative Research in Accounting and Management, 8(4), 382-424. https://doi.org/10.1108/11766091111189891

Bergevärn, L. E., Mellemvik, F., \& Olson, O. (1995). Institutionalization of Municipal Accounting - A Comparative Study Between Sweden and Norway. Scandinavian Journal of Management, 11(1), 25-41. https://doi.org/10.1016/09565221(94)00024-C

Berle, Adolf A, J., \& Means, G. C. (1932). The Modern Corporation and Private Property. Harcourt, Brace \& World.

Bowman, W. (2002). The Uniqueness of Nonprofit Finance and the Decision to Borrow. Nonprofit Management and Leadership, 12(3), 293-311. https://doi.org/10.1002/nml.12306 
Charles, C. (2017). Nonprofit Arts Organizations : Debt Ratio Does Not Influence Donations - Interest Expense Ratio Does. American Review of Public Administration, 48(7), 659-667. https://doi.org/10.1177/0275074017724227

Cohen, S., \& Karatzimas, S. (2018). The role of the Troika on the Greek central government accounting reforms: The reprioritization riddle. International Journal of Public Sector Management, 32(3), 316-330. https://doi.org/10.1108/IJPSM-06-2016-0101

Copley, P. A., \& Douthett, E. B. (2014). Are governmental accounting measures value relevant to the citizenry? Journal of Public Budgeting, Accounting \& Financial Management, 26(4), 583-613. https://doi.org/10.1108/JPBAFM-26-04-2014B003

Fama, E. F., \& Jensen, M. C. (1983). Separation of Ownership and Control. The Journal of Law \& Economics, 26(2), 301-325. http://www.jstor.org/stable/725104

Friedman, M. (1953). The Case for Flexible Exchange Rates. In: Essays in Positive Economics (pp. 157-203). University of Chicago Press.

Friedman, M. (1966). The Methodology of Positive Economic. In: Essays in Positive Economics (pp. 30-43). University of Chicago Press.

Gardini, S. G. G. (2014). Voluntary Adoption of the Consolidate. Journal of Public Budgeting, Accounting \& Financial Management, 26(2), 313-344. https://doi.org/10.1108/JPBAFM-26-02-2014-B004

Gigli, S., \& Mariani, L. (2018). Lost in The Transition From Cash To Accrual Accounting: Assessing The Knowledge Gaps In Italian Public Universities. International Journal of Public Sector Management, 31(7), 811-826. https://doi.org/10.1108/IJPSM-07-2017-0184

Gordon, G., \& Fischer, M. (2014). Public University Presidential Compensation: Performance, Cost Efficiency And Spending Choices. Journal of Public Budgeting, Accounting \& Financial Management, 26(4), 557-583. https://doi.org/10.1108/JPBAFM-26-04-2014-B002

Greiling, D., Traxler, A. A., \& Stötzer, S. (2015). Sustainability Reporting in The Austrian, German And Swiss Public Sector. International Journal of Public Sector Management, 28(4/5), 404-428. https://doi.org/10.1108/IJPSM-04-2015-0064

Guthrie, J., \& Parker, L. D. (1989). Corporate Social Reporting: A Rebuttal of Legitimacy Theory. Accounting and Business Research, 19(76), 343-352. https://doi.org/10.1080/00014788.1989.9728863

Jensen, M. C., \& Meckling, W. H. (1976). Theory of the Firm: Managerial Behavior, Agency Costs, and Ownership Structure. Journal of Financial Economics, 3(4), 305-360. https://doi.org/10.1177/0018726718812602

Kaplan, R.S., \& Norton, D. P. (1992). Balanced Scorecard - Measures That Drive Performance. Harvard Business Review, 70(1), 71-90.

Kaplan, Robert S, \& Johnson, H. T. (1987). Relevance Lost: The Rise and Fall of Management Accounting. Harvard Business School Press.

Kidwell, L., \& Lowensohn, S. (2018). Stakeholder Participation In The Governmental Accounting Standard-Setting Process. 30(2), 252-268. https://doi.org/10.1108/JPBAFM-02-2018-0019 


\section{Zamzami \& Mukhlis}

Public Accounting Research and Theories: A Literature Review

Lindblom, C. K. (1994). The Implications Of Organizational Legitimacy For Corporate Social Performance And Disclosure, Working Paper for the American Accounting Association Public Interest Section, USA. In Paper Presented at the Critical Perspectives on Accounting Conference.

Magnus, S. A., Smith, D., \& Wheeler, J. R. C. (2003). Agency Implications of Debt in Notfor-profit Hospitals: A Conceptual Framework and Overview. Research in Healthcare Financial Management, 8(1), 7-17.

Marcuccio, M., \& Steccolini, I. (2009). Patterns Of Voluntary Extended Performance Reporting In Italian Local Authorities. International Journal of Public Sector Management, 22(2), 146-167. https://doi.org/10.1108/09513550910934547

Myers, S. C. (1977). Determinants of Corporate Borrowing. Journal of Financial Economics, 5, 147-175. https://doi.org/10.1016/0304-405X(77)90015-0

Neu, D. (1991a). New Stock Issues And The Institutional Production Of Trust. Accounting, Organizations and Society, 16(2), 185-200. https://doi.org/10.1016/03613682(91)90013-5

Neu, D. (1991b). Trust, Contracting And The Prospectus Process. Accounting, Organizations and Society, 16(3), 243-256. https://doi.org/10.1016/03613682(91)90003-W

Neu, D. (1991c). Trust, Impression Management and the Public Accounting Profession. Critical Perspectives on Accounting, 2(3), 295-313. https://doi.org/10.1016/1045-2354(91)90015-6

Northcott, D., \& Taulapapa, T. M. (2012). Using The Balanced Scorecard To Manage Performance In Public Sector Organizations Issues And Challenges. International Journal of Public Sector Management, 25(3), 166-191. https://doi.org/10.1108/09513551211224234

Paulsson, G. (2006). Accrual Accounting in the Public Sector: Experiences from The Central Government in Sweden. Financial Accountability \& Management, 22(1), 47-62. https://doi.org/DOI: 10.1111/j.0267-4424.2006.00392.x

Plummer, E., \& Patton, T. K. (2015). Article information : Journal of Public Budgeting, Accounting \& Financial Management, 27(2), 225-264. https://doi.org/10.1108/JPBAFM-27-02-2015-B004

Prabowo, T. J. W., Leung, P., \& Guthrie, J. (2017). Reforms in Public Sector Accounting and Budgeting in Indonesia (2003-2015): Confusions in Implementation. Journal of Public Budgeting, Accounting and Financial Management, 29(1), 104-137. https://doi.org/10.1108/jpbafm-29-01-2017-b005

Ríos, A. M., Bastida, F., \& Benito, B. (2016). Budget Transparency and Legislative Budgetary Oversight: An International Approach. American Review of Public Administration, 46(5), 546-568. https://doi.org/10.1177/0275074014565020

Ritonga, I. T. (2020). Public Accounting and Business Accounting: Two Different Upstream. Journal of Accounting and Investment, 21(3), 401-416. https://doi.org/10.18196/jai.2103156

Roberts, R. W., \& Kurtenbach, J. M. (1992). An Analysis of Lobbying Activities Before the Governmental Accounting Standards Board. Research in Governmental and Nonprofit Accounting, 7, 25-40. 


\section{Zamzami \& Mukhlis}

Public Accounting Research and Theories: A Literature Review

Scott, W. R. (2004). Institutional Theory: Contributing to a Theoritical Research Program. Great Minds in Management: The Process of Theory Development. Oxford University Press.

Stalebrink, O. J. (2014). Public Pension Funds and Assumed Rates of Return: An Empirical Examination of Public Sector Defined Benefit Pension Plans. American Review of Public Administration, 44(1), 92-111. https://doi.org/10.1177/0275074012458826

Timoshenko, K., \& Adhikari, P. (2010). A two-country comparison of public sector accounting reforms: Same ideas, different paths? Journal of Public Budgeting, Accounting \& Financial Management, 22(4), 449-489. https://doi.org/10.1108/JPBAFM-22-04-2010-B001

Tomkins, C. (2001). Interdependencies, Trust and Information in Relationships, Alliances and Networks. Accounting, Organizations and Society, 26(2), 161-191. https://doi.org/10.1016/S0361-3682(00)00018-0

Verbeeten, F. H. M. (2011). Public Sector Cost Management Practices in The Netherlands. International Journal of Public Sector Management, 24(6), 492506. https://doi.org/10.1108/09513551111163620

Waluyo, B. (2018). Balancing Financial Autonomy and Control in Agencification: Issues Emerging from the Indonesian Higher Education. International Journal of Public Sector Management, 31(7), 794-810. https://doi.org/10.1108/IJPSM-10-20170272

Yetman, R. . (2007). Financing Nonprofits: Putting Theory Into Practice. Altamira Press.

Yinger, J. (1982). Capitalization and the Theory of Local Public Finance. Journal of Political Economy, 50(5), 917-943.

Zimmerman, J. L. (1977). Discussion of The Municipal Accounting Maze: An Analysis of Political Incentives. Journal of Accounting Research, 15(1977), 107-144. https://doi.org/10.2307/2490637 
Zamzami \& Mukhlis

Public Accounting Research and Theories: A Literature Review

Appendix 1. Journal of Public Budgeting, Accounting \& Financial Management

\begin{tabular}{|c|c|c|}
\hline Year & Title & Author \\
\hline 2009 & $\begin{array}{l}\text { Less is more: exploring citizen-based financial } \\
\text { reporting in local government }\end{array}$ & Kloby, K \\
\hline \multicolumn{3}{|c|}{ 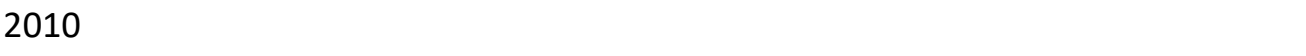 } \\
\hline & $\begin{array}{l}\text { Governmental accounting, global markets and } \\
\text { ideologies: A historical study of state and local } \\
\text { practices in the united states }\end{array}$ & $\begin{array}{l}\text { Sacco, J. F., } \\
\text { Stalebrink, O. J. }\end{array}$ \\
\hline & $\begin{array}{l}\text { Conceptualizing Financial Condition In Local } \\
\text { Government }\end{array}$ & $\begin{array}{l}\text { Rivenbark, W. C., } \\
\text { Roenigk, D. J., \& } \\
\text { Allison, G. S. }\end{array}$ \\
\hline & Accounting innovations: A contingent view on italian & Anessi-Pessina, E., \\
\hline & local governments & $\begin{array}{l}\text { Nasi, G. and } \\
\text { Steccolini, I. }\end{array}$ \\
\hline & $\begin{array}{l}\text { A two-country comparison of public sector } \\
\text { accounting reforms: Same ideas, different paths? }\end{array}$ & $\begin{array}{l}\text { Timoshenko, } K . \\
\text { and Adhikari, P. }\end{array}$ \\
\hline & $\begin{array}{l}\text { Dutch local accounting committees: A committee } \\
\text { chair's experience }\end{array}$ & van der Hoek, $M$. \\
\hline 2011 & - & - \\
\hline \multirow[t]{2}{*}{2012} & $\begin{array}{l}\text { Double (Accounting) Standards: A Comparison Of } \\
\text { Public And Private Sector Defined Benefit Pension } \\
\text { Plans }\end{array}$ & $\begin{array}{l}\text { Easterday, K. and } \\
\text { Eaton, T. }\end{array}$ \\
\hline & $\begin{array}{l}\text { Two accounting standard setters: Divergence } \\
\text { continues for nonprofit organizations }\end{array}$ & $\begin{array}{l}\text { Fischer, M. and } \\
\text { Marsh, T. }\end{array}$ \\
\hline \multirow[t]{2}{*}{2013} & $\begin{array}{l}\text { Charitable ratings and financial reporting quality: } \\
\text { Evidence from the human service sector }\end{array}$ & $\begin{array}{l}\text { Ling, Q. and } \\
\text { Gordon Neely, D. }\end{array}$ \\
\hline & $\begin{array}{l}\text { Going-concern modified audit opinions for non-profit } \\
\text { organizations }\end{array}$ & $\begin{array}{l}\text { Vermeer, } \quad T ., \\
\text { Raghunandan, } K . \\
\text { and Forgione, } D .\end{array}$ \\
\hline \multirow[t]{6}{*}{2014} & $\begin{array}{l}\text { Are governmental accounting measures value } \\
\text { relevant to the citizenry? }\end{array}$ & $\begin{array}{l}\text { Copley, } P . \quad \text { and } \\
\text { Douthett, } E .\end{array}$ \\
\hline & $\begin{array}{l}\text { Accounting professionalism and local government } \\
\text { gaap adoption: A national study }\end{array}$ & $\begin{array}{l}\text { Khumawala, S., } \\
\text { Marlowe, J. and } \\
\text { Gordon Neely, D. }\end{array}$ \\
\hline & $\begin{array}{l}\text { Voluntary adoption of the consolidated financial } \\
\text { statement and fair value accounting by italian local } \\
\text { governments }\end{array}$ & $\begin{array}{l}\text { Gardini, S. and } \\
\text { Grossi, G. }\end{array}$ \\
\hline & $\begin{array}{l}\text { Developments and challenges in public sector } \\
\text { accounting }\end{array}$ & García, F. M. \\
\hline & $\begin{array}{l}\text { Symposium on financial sustainability of the public } \\
\text { sector: A critical issue for the stakeholders }\end{array}$ & $\begin{array}{l}\text { Bergmann, A. and } \\
\text { Grossi, G. }\end{array}$ \\
\hline & $\begin{array}{l}\text { A politico-economic perspective on financial } \\
\text { sustainability }\end{array}$ & $\begin{array}{l}\text { Slembeck, T., Jans, } \\
\text { A. and Leu, T. }\end{array}$ \\
\hline 2015 & $\begin{array}{l}\text { Using financial statements to provide evidence on } \\
\text { the fiscal sustainability of the states } \\
\text { Municipal accounting restatements and top financial } \\
\text { manager turnover }\end{array}$ & $\begin{array}{l}\text { Plummer, E. and } \\
\text { Patton, T. } \\
\text { Rich, K. and Zhang, } \\
\text { J. }\end{array}$ \\
\hline
\end{tabular}


Zamzami \& Mukhlis

Public Accounting Research and Theories: A Literature Review

\begin{tabular}{|c|c|c|}
\hline Year & Title & Author \\
\hline 2016 & - & - \\
\hline 2017 & $\begin{array}{l}\text { Reforms in public sector accounting and budgeting in } \\
\text { Indonesia (2003-2015): confusions in } \\
\text { implementation }\end{array}$ & $\begin{array}{l}\text { Jatmiko Wahyu } \\
\text { Prabowo, } \\
\text { Leung, P. } \\
\text { Guthrie, J. }\end{array}$ \\
\hline \multirow[t]{4}{*}{2018} & $\begin{array}{l}\text { Do donors respond to discretionary accounting } \\
\text { information consolidation? } \\
\text { Effects of the GASB No. } 34 \text { infrastructure reporting } \\
\text { standards on state highway infrastructure quality: A } \\
\text { panel data analysis }\end{array}$ & $\begin{array}{l}\text { Quosigk, B. and } \\
\text { Forgione, D. } \\
\text { Kim, J., Chen, C., \& } \\
\text { Ebdon, C. }\end{array}$ \\
\hline & $\begin{array}{l}\text { Public sector consolidated financial statements: a } \\
\text { structured literature review }\end{array}$ & $\begin{array}{l}\text { Santis, S., Grossi, } \\
\text { G., \& Bisogno, M. }\end{array}$ \\
\hline & $\begin{array}{l}\text { Stakeholder participation in the governmental } \\
\text { accounting standard-setting process }\end{array}$ & $\begin{array}{l}\text { Kidwell, L., } \quad \& \\
\text { Lowensohn, S. }\end{array}$ \\
\hline & $\begin{array}{l}\text { The effect of GAAP conformity on pension } \\
\text { underfunding }\end{array}$ & $\begin{array}{l}\text { Davidyan, J. Y., \& } \\
\text { Waymire, T. R. }\end{array}$ \\
\hline
\end{tabular}

Source: Processed data, 2020

Appendix 2. Accounting, Auditing \& Accountability Journal

\begin{tabular}{cll}
\hline Year & \multicolumn{1}{c}{ Title } & \multicolumn{1}{c}{ Author } \\
\hline 2015 & Public sector accounting, accountability and & Bracci, E., Humphrey, C., \\
& austerity: more than balancing the books?' & Moll, J., \& Steccolini, I. \\
\cline { 3 - 3 } & Accounting for austerity: the Troika in the & Cohen, S., Guillamón, M.- \\
& Eurozone & D., Lapsley, l., \& Robbins, \\
& & G. \\
& Will "austerity" be a critical juncture in & Heald, D., \& Hodges, R. \\
& European public sector financial reporting? & \\
\hline
\end{tabular}

Source: Processed data, 2020

Appendix 3. International Journal of Public Sector Management

\begin{tabular}{|c|c|c|}
\hline Year & Title & Author \\
\hline 2009 & $\begin{array}{l}\text { Politicians versus managers: roles and } \\
\text { interactions in accounting cycles } \\
\text { Patterns of voluntary extended performance } \\
\text { reporting in Italian local authorities }\end{array}$ & $\begin{array}{l}\text { Liguori, M., Sicilia, M., \& } \\
\text { Steccolini, I. } \\
\text { Marcuccio, M., \& } \\
\text { Steccolini, I. }\end{array}$ \\
\hline 2010 & $\begin{array}{l}\text { Stakeholder salience and accounting } \\
\text { practices in Tanzanian NGOs }\end{array}$ & $\begin{array}{l}\text { Assad, M. J., \& Goddard, } \\
\text { A. R. }\end{array}$ \\
\hline 2011 & - & - \\
\hline 2012 & - & - \\
\hline 2013 & - & - \\
\hline 2014 & - & - \\
\hline 2015 & $\begin{array}{l}\text { Sustainability reporting in the Austrian, } \\
\text { German and Swiss public sector }\end{array}$ & $\begin{array}{l}\text { Greiling, D., Traxler, A. } \\
\text { A., \& Stötzer, S. }\end{array}$ \\
\hline 2016 & $\begin{array}{l}\text { Tracing the future of reporting in the public } \\
\text { sector: introducing integrated popular }\end{array}$ & $\begin{array}{l}\text { Cohen, S., \& Karatzimas, } \\
\text { S. }\end{array}$ \\
\hline
\end{tabular}




\begin{tabular}{lll}
\hline 2017 & reporting & \\
2018 & $\begin{array}{l}\text { Lost in the transition from cash to accrual } \\
\text { accounting: Assessing the knowledge gaps in } \\
\text { Italian public universities }\end{array}$ & \\
\hline
\end{tabular}

Source: Processed data, 2020

Appendix 4. Jurnal The American Review of Public Administration

\begin{tabular}{|c|c|c|}
\hline Year & Title & Author \\
\hline 2009 & $\begin{array}{l}\text { Developing a Model to Measure Financial } \\
\text { Condition in Local Government: Evaluating } \\
\text { Service Quality and Minimizing the Effects of } \\
\text { the Socioeconomic Environment: An } \\
\text { Application to Spanish Municipalities }\end{array}$ & $\begin{array}{l}\text { Zafra, José \& López- } \\
\text { Hernández, Antonio \& } \\
\text { Agustín, Hernández- } \\
\text { Bastida }\end{array}$ \\
\hline 2010 & - & - \\
\hline 2011 & - & - \\
\hline 2012 & - & - \\
\hline 2013 & - & - \\
\hline 2014 & $\begin{array}{l}\text { Public Pension Funds and Assumed Rates of } \\
\text { Return: An Empirical Examination of Public } \\
\text { Sector Defined Benefit Pension Plans }\end{array}$ & Stalebrink, O. J. \\
\hline 2015 & - & - \\
\hline 2016 & - & - \\
\hline 2017 & $\begin{array}{l}\text { Transparency in Governments: A Meta- } \\
\text { Analytic Review of Incentives for Digital } \\
\text { Versus Hard-Copy Public Financial } \\
\text { Disclosures } \\
\text { Local Government Strategies for Financing } \\
\text { Energy Efficiency Initiatives }\end{array}$ & $\begin{array}{l}\text { Muñoz, Laura \& } \\
\text { Rodríguez Bolívar, Manuel } \\
\text { Pedro \& López- } \\
\text { Hernández, Antonio } \\
\text { Wang, Xiaohu \& Cheol, } \\
\text { Liu \& Hawkins, } \\
\text { Christopher }\end{array}$ \\
\hline \multirow[t]{5}{*}{2018} & $\begin{array}{l}\text { Nonprofit Arts Organizations: Debt Ratio } \\
\text { Does Not Influence Donations-Interest } \\
\text { Expense Ratio Does }\end{array}$ & Charles, Cleopatra \\
\hline & $\begin{array}{l}\text { What is the stock of the situation? A } \\
\text { bibliometric analysis on social and } \\
\text { environmental accounting research in public } \\
\text { sector }\end{array}$ & Floriana Fusco, Paolo Ricci \\
\hline & $\begin{array}{l}\text { Financial disclosure practices among } \\
\text { Malaysian local authorities: a case study }\end{array}$ & $\begin{array}{l}\text { Neilson Anak Teruki, } \\
\text { Robert Ochoki Nyamori, } \\
\text { Kamran Ahmed }\end{array}$ \\
\hline & $\begin{array}{l}\text { Lost in the transition from cash to accrual } \\
\text { accounting: Assessing the knowledge gaps in } \\
\text { Italian public universities }\end{array}$ & $\begin{array}{l}\text { Sabrina Gigli, Laura } \\
\text { Mariani }\end{array}$ \\
\hline & $\begin{array}{l}\text { The role of the Troika on the Greek central } \\
\text { government accounting reforms: The } \\
\text { reprioritization riddle }\end{array}$ & $\begin{array}{l}\text { Cohen, S. and Karatzimas, } \\
\text { S. }\end{array}$ \\
\hline
\end{tabular}


Source: Processed data, 2020

Appendix 5. Journal of Public Budgeting, Accounting \& Financial Management

\begin{tabular}{|c|c|c|}
\hline Year & Title & Author \\
\hline 2009 & $\begin{array}{l}\text { 1. Citizen participation in the budget process: } \\
\text { the effect of city managers } \\
\text { 2. Citizens, budgets and performance } \\
\text { measures: a case study of west hartford, } \\
\text { connecticut }\end{array}$ & $\begin{array}{l}\text { Yahong Zhang, Kaifeng } \\
\text { Yang } \\
\text { Mark D. Robbins, Bill } \\
\text { Simonsen, Emily Shepard }\end{array}$ \\
\hline 2010 & - & - \\
\hline 2011 & $\begin{array}{l}\text { 1. The declining use of internal service funds: } \\
\text { how local governments are changing the } \\
\text { allocation of indirect costs }\end{array}$ & Steve Modlin \\
\hline & $\begin{array}{l}\text { 2. Performance reporting: Assessing citizen } \\
\text { access to performance measures on state } \\
\text { government websites }\end{array}$ & $\begin{array}{l}\text { Judith A. Harris, Karen S. } \\
\text { McKenzie, Randall W. } \\
\text { Rentfro }\end{array}$ \\
\hline 2012 & - & - \\
\hline 2013 & - & - \\
\hline \multirow[t]{2}{*}{2014} & $\begin{array}{l}\text { Public university presidential compensation: } \\
\text { Performance, cost efficiency and spending } \\
\text { choices }\end{array}$ & $\begin{array}{l}\text { Gus Gordon, Mary } \\
\text { Fischer }\end{array}$ \\
\hline & $\begin{array}{l}\text { Smart cuts?: Strategic planning, performance } \\
\text { management and budget cutting in U.S. cities } \\
\text { during the great recession }\end{array}$ & Benedict S. Jimenez \\
\hline 2015 & - & - \\
\hline 2016 & - & - \\
\hline 2017 & - & - \\
\hline 2018 & - & - \\
\hline
\end{tabular}

Source: Processed data, 2020

Appendix 6. International Journal of Public Sector Management

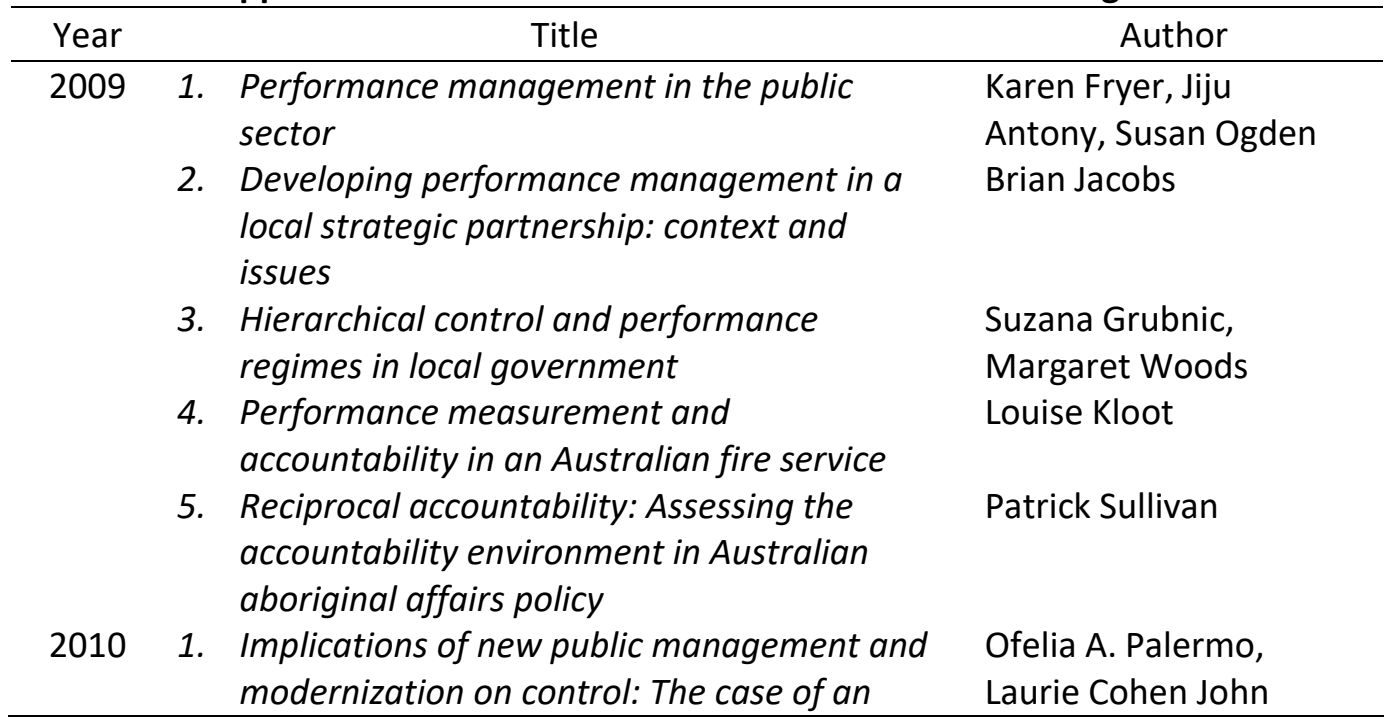


Zamzami \& Mukhlis

Public Accounting Research and Theories: A Literature Review

\begin{tabular}{|c|c|c|}
\hline Year & Title & Author \\
\hline & English regional probation service & $\begin{array}{l}\text { Loan-Clarke, Kamel } \\
\text { Mellahi }\end{array}$ \\
\hline & $\begin{array}{l}\text { An institutional review of planning budgeting } \\
\text { and monitoring in the Caribbean: Challenges } \\
\text { of transformation }\end{array}$ & Ann Marie Bissessar \\
\hline \multirow[t]{4}{*}{2011} & $\begin{array}{l}\text { 1. Towards the next generation of public } \\
\text { management: A study of management } \\
\text { control and communication in the Swedish } \\
\text { Armed Forces }\end{array}$ & $\begin{array}{l}\text { Roland Almqvist, Bino } \\
\text { Catasu's, Matti Skoog }\end{array}$ \\
\hline & $\begin{array}{l}\text { 2. Australian Federal Police drug investigations: } \\
\text { benefit-cost analysis }\end{array}$ & $\begin{array}{l}\text { Michael McFadden, } \\
\text { Toni-Lee Porter }\end{array}$ \\
\hline & $\begin{array}{l}\text { 3. Performance measurement and the UK } \\
\text { emergency ambulance service: Unintended } \\
\text { consequences of the ambulance response } \\
\text { time targets }\end{array}$ & Paresh Wankhade \\
\hline & $\begin{array}{l}\text { 4. Public sector cost management practices in } \\
\text { The Netherlands }\end{array}$ & Frank H.M. Verbeeten \\
\hline \multirow[t]{3}{*}{2012} & $\begin{array}{l}\text { 1. Using the balanced scorecard to manage } \\
\text { performance in public sector organizations: } \\
\text { Issues and challenges }\end{array}$ & $\begin{array}{l}\text { Deryl Northcott, Tuivaiti } \\
\text { Ma'amora Taulapapa }\end{array}$ \\
\hline & $\begin{array}{l}\text { 2. New public management, accounting, } \\
\text { regulators and moral panics }\end{array}$ & Bill Lee \\
\hline & $\begin{array}{l}\text { 3. Perceptions of performance in US financial } \\
\text { regulatory programs }\end{array}$ & $\begin{array}{l}\text { Thomas J. Greitens, M. } \\
\text { Ernita Joaquin }\end{array}$ \\
\hline \multirow[t]{3}{*}{2013} & $\begin{array}{l}\text { Overcoming challenges in the } \\
\text { implementation of performance } \\
\text { measurement: Case studies in public welfare } \\
\text { services }\end{array}$ & $\begin{array}{l}\text { Aki Jääskeläinen, Virpi } \\
\text { Sillanpää }\end{array}$ \\
\hline & $\begin{array}{l}\text { 2. Public sector reform: an overview of recent } \\
\text { literature and research on NPM and } \\
\text { alternative paths }\end{array}$ & $\begin{array}{l}\text { Michiel De Vries, Juraj } \\
\text { Nemec }\end{array}$ \\
\hline & $\begin{array}{l}\text { Austerity and financial governance: a UK } \\
\text { case study of the National Health Service }\end{array}$ & $\begin{array}{l}\text { Malcolm Prowle, Don } \\
\text { Harradine }\end{array}$ \\
\hline 2014 & $x_{0}$ & - \\
\hline 2015 & $\begin{array}{l}\text { Performance reporting in Ireland: the ongoing } \\
\text { gap between rhetoric and reality }\end{array}$ & Francis McGeough \\
\hline 2016 & $\begin{array}{l}\text { Post-NPM-style service integration: partnership- } \\
\text { based brokerage in elderly care }\end{array}$ & $\begin{array}{l}\text { Ari-Veikko Anttiroiko, } \\
\text { Pekka Valkama }\end{array}$ \\
\hline 2017 & $\begin{array}{l}\text { The use of performance measurement in } \\
\text { universities }\end{array}$ & Zhivan Alach \\
\hline 2018 & $\begin{array}{l}\text { Balancing financial autonomy and control in } \\
\text { agencification: Issues emerging from the } \\
\text { Indonesian higher education }\end{array}$ & Budi Waluyo \\
\hline
\end{tabular}

Source: Processed data, 2020 
Zamzami \& Mukhlis

Public Accounting Research and Theories: A Literature Review

Appendix 7. The American Review of Public Administration

\begin{tabular}{|c|c|c|}
\hline Year & Title & Author \\
\hline 2009 & $\begin{array}{l}\text { Developing a Model to Measure Financial } \\
\text { Condition in Local Government: Evaluating } \\
\text { Service Quality and Minimizing the Effects of } \\
\text { the Socioeconomic Environment: An } \\
\text { Application to Spanish Municipalities }\end{array}$ & $\begin{array}{l}\text { José Luis Zafra-Gómez } \\
\text { Antonio Manuel López- } \\
\text { Hernández Agustín } \\
\text { Hernández-Bastida }\end{array}$ \\
\hline 2010 & - & - \\
\hline 2011 & - & - \\
\hline 2012 & $\begin{array}{l}\text { Do Local Governments Save and Spend Across } \\
\text { Budget Cycles? Evidence From North Carolina }\end{array}$ & Wen Wang, Yilin Hou \\
\hline 2013 & - & - \\
\hline 2014 & - & - \\
\hline 2015 & - & - \\
\hline 2016 & $\begin{array}{l}\text { Budget Transparency and Legislative Budgetary } \\
\text { Oversight: An International Approach }\end{array}$ & $\begin{array}{l}\text { Ana-María Ríos, } \\
\text { Francisco Bastida, } \\
\text { Bernardino Benito }\end{array}$ \\
\hline 2017 & $\begin{array}{l}\text { Does the Program Manager Matter? New } \\
\text { Public Management and Defense Acquisition }\end{array}$ & $\begin{array}{l}\text { Adam Eckerd, Keith } \\
\text { Snider }\end{array}$ \\
\hline 2018 & $\begin{array}{l}\text { Citizen-Assisted Performance Measurement? } \\
\text { Reassessing Its Viability and Impact } \\
\text { Do Public Employees "Game" Performance } \\
\text { Budgeting Systems? Evidence From the } \\
\text { Program Assessment Rating Tool in Korea }\end{array}$ & $\begin{array}{l}\text { David N. Ammons, } \\
\text { Patrick M. Madej } \\
\text { Hosung Sohn, Kwang } \\
\text { Bin Bae }\end{array}$ \\
\hline & $\begin{array}{l}\text { An Open Systems Model of Local Government } \\
\text { Forecasting }\end{array}$ & Vincent Reitano \\
\hline
\end{tabular}

Source: Processed data, 2020

Appendix 8. Journal of Public Budgeting, Accounting \& Financial Management

\begin{tabular}{|c|c|c|}
\hline Year & Title & Author \\
\hline \multirow[t]{2}{*}{2009} & $\begin{array}{l}\text { The diligence of audit committees in the } \\
\text { healthcare sector }\end{array}$ & $\begin{array}{l}\text { Thomas E. Vermeer, } \\
\text { K. Raghunandan, } \\
\text { Dana A. Forgione }\end{array}$ \\
\hline & $\begin{array}{l}\text { Audited financial statements in the federal } \\
\text { government: Intentions, outcomes and on- } \\
\text { going challenges for management and policy- } \\
\text { making }\end{array}$ & Douglas A. Brook \\
\hline 2010 & $\begin{array}{l}\text { The Uncertain Future Of Accountability } \\
\text { Reporting } \\
\text { In The Shadow Of Corporate Scandal: The Use } \\
\text { Of Audit Committees In U.S. Local Governments }\end{array}$ & $\begin{array}{l}\text { Sam M. McCall, William } \\
\text { Earle Klay } \\
\text { David S. T. Matkin }\end{array}$ \\
\hline 2011 & - & - \\
\hline 2012 & $\begin{array}{l}\text { Determinants of auditee adoption of audit } \\
\text { recommendations: Local government auditors' } \\
\text { perspectives }\end{array}$ & $\begin{array}{l}\text { Stephen Kwamena } \\
\text { Aikins }\end{array}$ \\
\hline & county government finance practices: What & Steve Modlin \\
\hline
\end{tabular}


Public Accounting Research and Theories: A Literature Review

\begin{tabular}{|c|c|c|}
\hline Year & Title & Author \\
\hline & $\begin{array}{l}\text { independent auditors are finding and what } \\
\text { makes local government susceptible }\end{array}$ & \\
\hline & $\begin{array}{l}\text { An empirical investigation of audit fees in the } \\
\text { us for-profit healthcare sector }\end{array}$ & $\begin{array}{l}\text { Xiaoli (Charlie) Yuan, } \\
\text { Dennis M. López, Dana } \\
\text { A. Forgione }\end{array}$ \\
\hline \multirow[t]{2}{*}{2013} & $\begin{array}{l}\text { Auditor size and internal control reporting } \\
\text { differences in nonprofit healthcare } \\
\text { organizations }\end{array}$ & $\begin{array}{l}\text { Dennis M. López, Kevin } \\
\text { T. Rich, Pamela C. Smith }\end{array}$ \\
\hline & $\begin{array}{l}\text { Audited financial statements in the us federal } \\
\text { government: The question of policy and } \\
\text { management utility }\end{array}$ & Douglas A. Brook, \\
\hline 2014 & $\begin{array}{l}\text { Determining county government fiscal } \\
\text { instability: Independent audit report findings } \\
\text { and the prompting of state action }\end{array}$ & $\begin{array}{l}\text { Steve Modlin, LaShonda } \\
\text { M. Stewart }\end{array}$ \\
\hline 2015 & $\begin{array}{l}\text { Nonprofit organizations' choice in favor of a } \\
\text { sector expert auditor: a study of behavioral } \\
\text { choice criteria }\end{array}$ & $\begin{array}{l}\text { Anne-Mie Reheul, Tom } \\
\text { Van Caneghem, Sandra } \\
\text { Verbruggen, }\end{array}$ \\
\hline 2016 & - & - \\
\hline 2017 & - & - \\
\hline 2018 & - & - \\
\hline
\end{tabular}

Source: Processed data, 2020

Appendix 9. International Journal of Public Sector Management

\begin{tabular}{|c|c|c|}
\hline Year & Title & Author \\
\hline 2009 & - & - \\
\hline 2010 & The public value of the National Audit Office & Colin Talbot, Jay Wiggan \\
\hline 2011 & $\begin{array}{l}\text { Value for money and the rule of law: the } \\
\text { (new) performance audit in Sweden }\end{array}$ & $\begin{array}{l}\text { Anders Grönlund, Fredrik } \\
\text { Svärdsten, Peter Öhman }\end{array}$ \\
\hline 2012 & - & - \\
\hline 2013 & - & - \\
\hline 2014 & - & - \\
\hline 2015 & - & - \\
\hline 2016 & $\begin{array}{l}\text { Contribution of internal auditing to risk } \\
\text { management: Perceptions of public sector } \\
\text { senior management }\end{array}$ & Philna P Coetzee \\
\hline 2017 & - & - \\
\hline 2018 & $\begin{array}{l}\text { Is auditing the new evaluation? Can it be? } \\
\text { Should it be? }\end{array}$ & $\begin{array}{l}\text { Jon Pierre, B. Guy Peters, } \\
\text { Jenny de Fine Licht, }\end{array}$ \\
\hline
\end{tabular}

Source: Processed data, 2020

Appendix 10. The American Review of Public Administration

\begin{tabular}{llll}
\hline Year & Title & & Author \\
\hline 2009 & - & & - \\
$2010-$ & & - & \\
\hline
\end{tabular}


Zamzami \& Mukhlis

Public Accounting Research and Theories: A Literature Review

\begin{tabular}{lll}
\hline Year & \multicolumn{1}{c}{ Title } & \multicolumn{1}{c}{ Author } \\
\hline 2011 & - & - \\
2012 & - & - \\
2013 & - & - \\
2014 & - & - \\
2015 & - & - \\
2016 & - & - \\
2017 & - & - \\
& The De Facto Independence of Federal Offices & Robin J. Kempf, Jessica C. \\
2018 & $\begin{array}{l}\text { of Inspector General } \\
\text { Federal Offices of the Inspector General: } \\
\\
\end{array}$ Thriving on Chaos? & $\begin{array}{l}\text { Kathryn Newcomer, } \\
\text { George Grob }\end{array}$ \\
\hline
\end{tabular}

Source: Processed data, 2020 